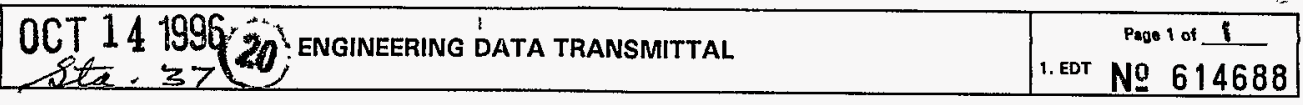

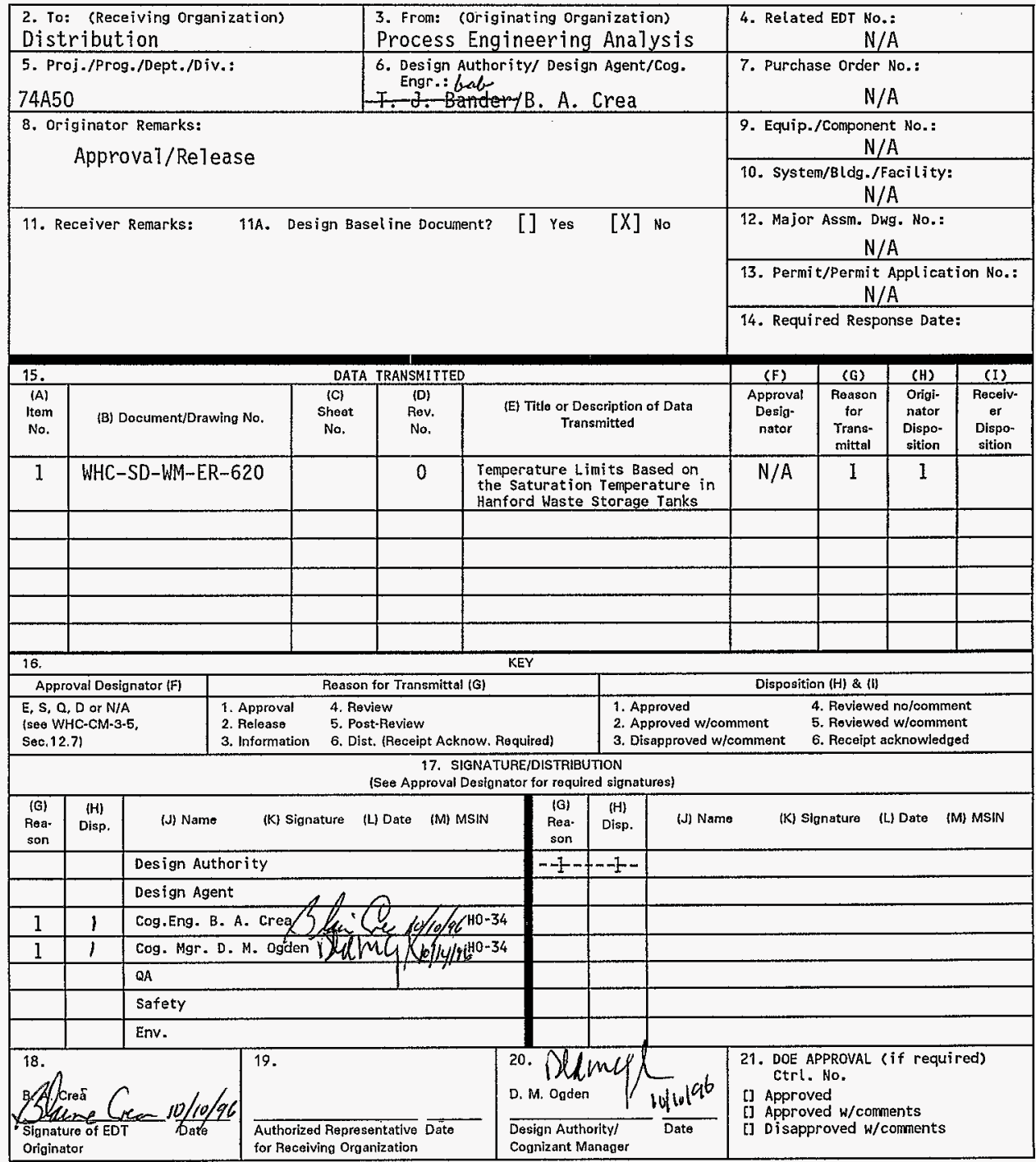

BD-7400-172-2(05/96). GEF097 


\section{Temperature Limits Based on the Saturation Temperature in Hanford Waste Storage Tanks}

T. J. Bander/B. A. Crea

Westinghouse Hanford Company, Richland, WA 99352

U.S. Department of Energy Contract DE-ACO6-87RL10930

EDT/ECN: 614688

UC: 2020

Org Code: $74 A 50$

Charge Code: N2218

B\&R Code: EW3135040 Tota1 Pages: 36

Key Words: Single-She1] Waste Tank

Double-Shell Waste Tank

Saturation Temperature

Temperature Limit

Abstract: This report calculates limits on the measured temperature readings to 7 imit the occurrence of saturation temperatures in Hanford waste storage tanks. The results in this report show that the temperature reported by a thermocouple tree in a double-shell tank can be significantly below the maximum waste temperature and that provisions should be made for that offset in any tank temperature monitoring program. The results for single-shell tanks show that some tanks may be at or above the saturation temperature.

TRADEMARK DISCLAIMER. Reference herein to any specific commercial product, process, or service by trade name, trademark, manufacturer, or otherwise, does not necessarily constitute or imply its endorsement, recommendation, or favoring by the United States Government or any agency thereof or its contractors or subcontractors.

Printed in the United States of America. To obtain copjes of this document, contact: WHC/BCS Document Control Services, P.O. Box 1970, Mailstop HG-08, Richland WA 99352, Phone (509) 372-2420; Fax (509) 376-4989.
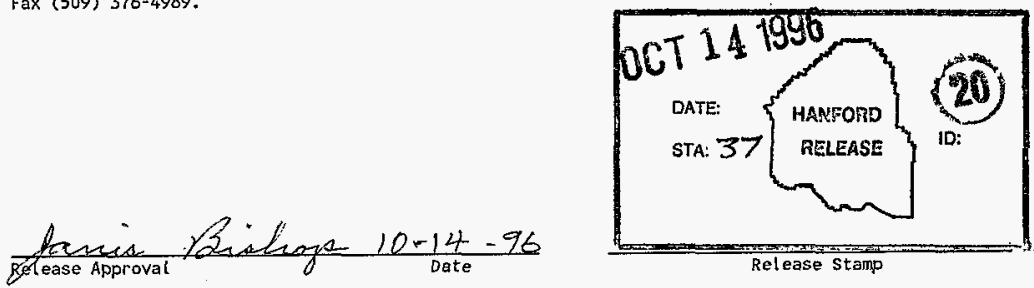
WHC-SD-WM-ER-620, Rev. 0

TEMPERATURE LIMITS BASED ON THE SATURATION TEMPERATURE

IN HANFORD WASTE STORAGE TANKS

T. J. Bander

B. A. Crea

D. M. Ogden

September 1996
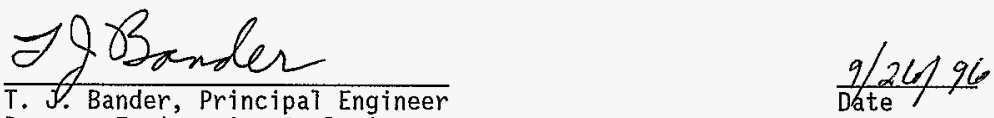

Process Engineering Analysis
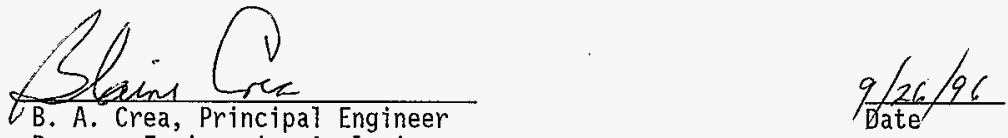

Process Engineering Analys is

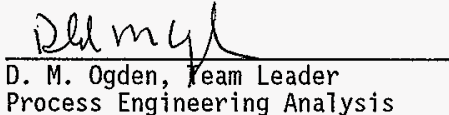

$\frac{1010196}{\text { Date }}$

Issued by

WESTINGHOUSE HANFORD COMPANY

for the

U.S. DEPARTMENT OF ENERGY

RICHLAND OPERATIONS OFFICE

RICHLAND, WASHINGTON 


\section{CONTENTS}

1.0 INTRODUCTION . . . . . . . . . . . . . . . . . . 1

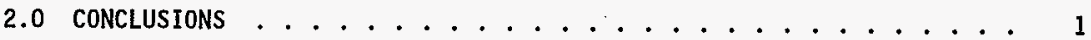

3.0 DESCRIPTION OF COMPUTER MODELS . . . . . . . . . . . . . . . . 2

3.1 ATTRIBUTES COMMON TO BOTH SINGLE AND DOUBLE-SHELL TANK MODELS . . . . . . . . . . . . . 2

3.2 DOUBLE-SHELL TANK MODEL GEOMETRY AND BOUNDARY CONDITIONS : * : 2

3.3 SINGLE-SHELL TANK MODEL GEOMETRY AND BOUNDARY CONDITIONS . . . 5

3.3.1 C Tanks ................... 5

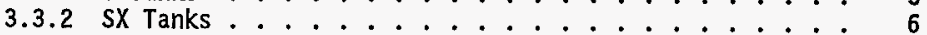

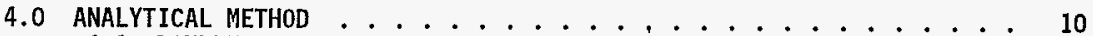

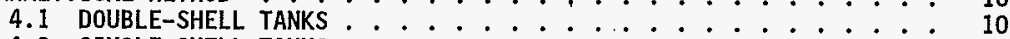

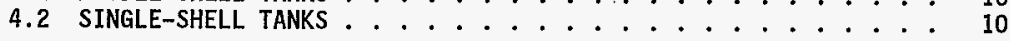

5.0 RESULTS OF ANALYSES ...................... 11

5.1 DOUBLE-SHELL TANKS ..................... 11

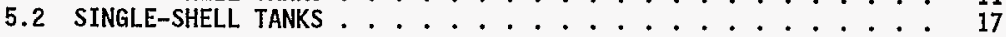

6.0 RECOMMENDATIONS FOR FURTHER WORK . . . . . . . . . . . . 32

7.0 REFERENCES . . . . . . . . . . . . . . . . . . 32

\section{FIGURES}

3.2.1. Double-Shell Tank Model Geometry . . . . . . . . . . . . . . 4

3.3.1. Entire Thermal Model for One million gal Single-Sheli Tank . . . 7

3.3.2. C-Tank Thermal Model ................. 8

3.3.3. SX-Tank Thermal Model . . . . . . . . . . . . . . . 9

5.1.1. Temperature Offset Profile for Case With $24 \mathrm{ft}$ of Siudge. . $_{0} \cdot 16$

5.2.1. Tank 241-C-105 Temperatures: Measured and Calculated . . . . . 23

5.2.2. Tank 241-SX-103 Temperatures: Measured and Calculated. . . . . . 24

5.2.3. Tank 241-SX-107 Temperatures: Measured and Calculated . . . . . . 25

5.2.4. Tank 241-SX-108 Temperatures: Measured and Calculated . . . . . . 26

5.2.5. Tank 241-SX-109 Temperatures: Measured and Calculated. . . . . . 27

5.2.6. Tank 241-SX-110 Temperatures: Measured and Calculated . . . . . . 28

5.2.7. Tank 241-SX-111 Temperatures: Measured and Calculated. . . . . . 29

5.2.8. Tank 241-SX-112 Temperatures: Measured and Calculated . . . . . . 30

5.2.9. Tank 241-SX-114 Temperatures: Measured and Calculated . . . . . 31 
TABLES

3.1.1. Thermal Properties ............... 2

5.1.1. Saturation Temperature as a Function of Sludge Depth . . . . 11

5.1.2. Thermocouple offset from Saturation $\left(F^{\circ}\right)$ for $2 \mathrm{ft}$ of sludge ... 12

5.1.3. Thermocoup Te offset from Saturation $\left(\mathrm{F}^{0}\right)$ for $6 \mathrm{Ft}$ of Sludge . . 12

5.1.4. Thermocouple offset from Saturation $\left(\mathrm{F}^{\circ}\right)$ for $12 \mathrm{ft}$ of sludge $\ldots 12$

5.1.5. Thermocouple offset from Saturation $\left(F^{\circ}\right)$ for $18 \mathrm{ft}$ of S1udge . . 13

5.1.6. Thermocouple offset from Saturation $\left(F^{\circ}\right)$ for $24 \mathrm{ft}$ of sludge . . 13

5.1.7. Thermocouple offset from Saturation $\left(\mathrm{F}^{\circ}\right)$ for $30 \mathrm{ft}$ of sludge . . 14

5.1.8. Thermocouple offset from Saturation $\left(F^{\circ}\right)$ for $36 \mathrm{ft}$ of STudge . . 15

5.2.1. Temperature Difference between Calculated and Measured

Temperatures at TC Tree Locations for Saturation Temperature at Center of Tank ................. 20

5.2.2. Temperatures of Calculated and Measured Temperatures at

TC Tree Locations for Saturation Temperature at Center of Tank . 21 
WHC-SD-WM-ER-620, Rev. 0

\section{TEMPERATURE LIMITS BASED ON THE SATURATION TEMPERATURE IN HANFORD WASTE STORAGE TANKS}

\subsection{INTRODUCTION}

Limits on the temperature of the waste in the waste storage tanks at Hanford are one of several means used to ensure that the storage of these radioactive wastes is conducted in a safe manner. The Limiting Conditions for Operations (LCO) temperature limit in Hanford waste tanks is $300^{\circ} \mathrm{F}$ (Dougherty 1996). For tanks with moist sludge or liquid layers, there is the possibility of a steam release event if temperatures in the tanks exceed the local saturation temperature. The saturation temperature limit for the conditions assumed in this study is 1 ower than $300^{\circ} \mathrm{F}$. The 1 imits are typically stated as applicable to the maximum waste temperature in a tank. However, there are no thermocouples (TCS) in most tanks at the point of maximum temperature, which is typically in the center of the tank. The results contained in this report use measured temperature readings to 1 imit the occurrence of saturation temperatures in Hanford waste storage tanks.

\subsection{CONCLUSIONS}

The results in this report show that the temperature reported by a thermocouple tree in a double-shell tank (DST) can be significantly below the maximum waste temperature and that provisions should be made for that offset in any tank temperature monitoring program.

The results for single-shell tanks (SST) were obtained by maintaining the maximum calculated temperature at or below the local saturation temperature. The SSTs 241-C-105 and 241-SX-103 have temperatures reported by the single TC tree in these tanks which are significantly below the calculated temperatures for all ventilation rates assumed. The SSTs 241-SX-107, 241-SX-109 through 241-SX-112, and 241-SX-114 have temperatures reported by the TC tree $19 \mathrm{ft}$ from the center of the tank which are about $20^{\circ} \mathrm{F}$ or more below the calculated temperatures for all ventilation rates assumed. Tank 241-SX-108 has temperatures reported by the TC trees which are above or close to the calculated temperatures. However, this tank has been recently sampled and the sludge is very dry, therefore temperatures above saturation are not an issue.

The TC tree $29 \mathrm{ft}$ from the center of the tank for SSTs 241-SX-107, 241-SX-110, 241-SX-111, and 241-SX-114 have temperatures reported by the TC tree which are above or close to the calculated temperatures. It is not known if these tanks are completely dry. A sludge sample from these tanks would provide the information to determine the need for further evaluation of these tanks. 


\subsection{DESCRIPTION OF COMPUTER MODELS}

\subsection{ATTRIBUTES COMMON TO BOTH SINGLE AND DOUBLE-SHELL TANK MODELS}

The thermal models were developed using the PATRAN' modeling program (PATRAN 1990) and solved with associated programs P/THERMAL ${ }^{2}$ (P/THERMAL 1991) and P/VIEWFACTOR ${ }^{3}$ (P/VIEWFACTOR 1991). PATRAN was used for pre- and post-processing. It is best described as a geometry model builder with the capability to define the geometry and associated boundary conditions in a discretized fashion that can be used by an analysis code. P/THERMAL was used as the analysis code. It is a finite element thermal solver that transforms the finite element based problem description from PATRAN into an equivatent network description. It has the capability to add other heat transfer boundary conditions such as thermal radiation and convection/advection terms to the model description. P/VIEWFACTOR is an adjunct program to P/THERMAL that defines radiation viewfactors based solely on geometric considerations. The viewfactors are defined based on the discretized geometry developed by PATRAN.

A11 analyses were conducted on a steady state basis. The thermal conductivities of the materials that are used in the models are as shown in Table 3.1.1 below. The same properties were used for both the SST and DST models.

Table 3.1.1. Thermal Properties.

\begin{tabular}{|l|c|}
\hline \multicolumn{1}{|c|}{ Material } & $\begin{array}{c}\text { Thermal conductivity } \\
\left.\mathrm{Btu} / \mathrm{h} \mathrm{ft}{ }^{\circ} \mathrm{F}\right)\end{array}$ \\
\hline \hline Air & 0.016 \\
\hline Concrete & 0.435 \\
\hline Soil (average) & 0.484 \\
\hline Waste (sludge) & 0.38 (nomina1) \\
\hline
\end{tabular}

\subsection{DOUBLE-SHELL TANK MODEL GEOMETRY AND BOUNDARY CONDITIONS}

A two-dimensional axisymmetric model of the tank and surrounding soif column was used to model a generic DST. The tank dimensions were taken from

${ }^{1}$ PATRAN is a registered trademark of the MacNeal-Schwendler Corporation.

${ }^{2} \mathrm{P} / \mathrm{THERMAL}$ is a registered trademark of the MacNea]-SchwendTer Corporation.

${ }^{3}$ P/VIEWFACTOR is a registered trademark of the MacNea1-Schwendler Corporation. 
Kaiser Engineer Hanford drawing ES-236A-Z1, Revision 0. A diagram of the finite element thermal model is shown in Figure 3.2.1. A cylindrical column of soil extending $70 \mathrm{ft}$ radially outward from the tank centerline and $200 \mathrm{ft}$ down from the soil surface to the water table was included.

The concrete pad on which the primary tank sits, the concrete surrounding the secondary liner, and the steel walls of the primary and secondary tanks are all included in the model. The air flow in the annulus region between the primary and secondary tanks and the air flow in the space between the waste surface and the tank dome is included in the model. The flow in the annulus is set at a value of $2000 \mathrm{scfm}$ and the flow in the tank dome is set at a value of $500 \mathrm{scfm}$. Both flows were set at the upper bound of the ventilation system, since this causes higher temperature gradients in the sludge. The inlet temperature for these flows is set at $-31^{\circ} \mathrm{F}$, which represents winter conditions at Hanford. This temperature condition is conservative compared to a higher inlet temperature, since it causes higher temperature gradients in the siudge.

Heat transfer by radiation and convection across the air space between the primary and secondary tanks and from the waste surface to the primary tank dome and walls was included in the model. The radiation and convection models in the tank dome change as the level of waste in the tank changes. Seven similar models were developed to model a DST with $36,30,24,18,12,6$, and $2 \mathrm{ft}$ of waste in the tank.

The heat transfer to the channels under the tank was simulated with an effective overall heat transfer coefficient; individual channels were not modeled. Consequently, the circumferential variations in temperature in the concrete pad caused by the placement of the cooling channels were not

The assumption was made that any supernate in the tanks was isothermal, and that the only effect of the supernate would be to increase the hydrostatic pressure in the sludge and thus the saturation temperature. If the supernate has the density of water then the change in saturation temperature to be added is $1.14^{\circ} \mathrm{F}$ per foot of supernate. 
Figure 3.2.1. Double-Shell Tank Mode] Geometry.

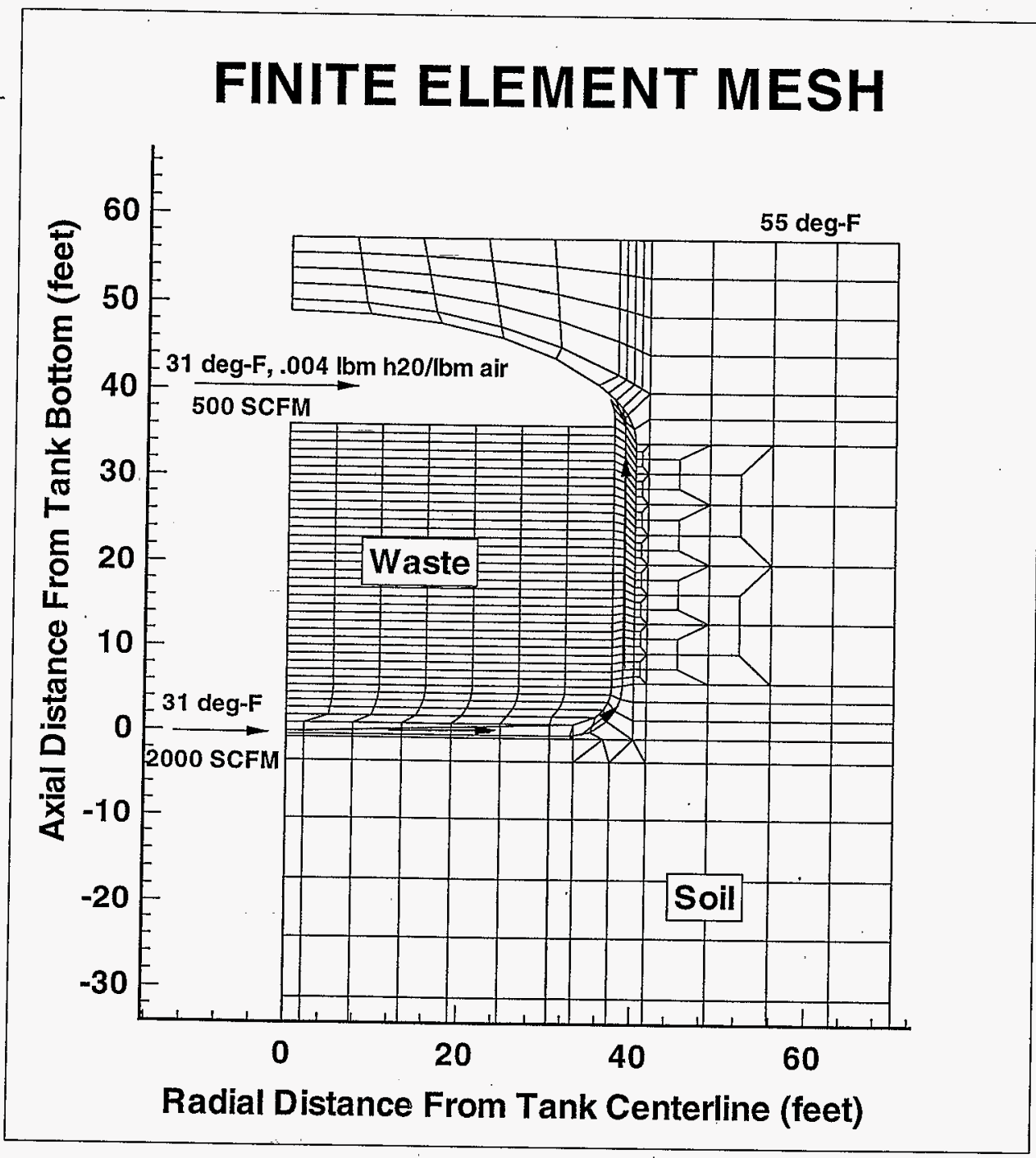


WHC-SD-WM-ER-620, Rev. 0

\subsection{SINGLE-SHELL TANK MODEL. GEOMETRY AND BOUNDARY CONDITIONS}

The thermal properties that were used for the analyses are as shown in Table 3.1.1. An emissivity of 0.9 (Kreith 1959) is used for all of the surfaces in the tank. Active ventilation, the flow of air through the tank, is modeled with an advective heat transfer element from the tank air volume to the outside air. The temperature of the ventilation air was assumed to be $31^{\circ} \mathrm{F}$. This is the temperature used in the DST modeling for ventilation air based on winter conditions at Hanford.

The boundary conditions on the soil surfaces are shown in Figure 3.3.1. An average annual air temperature of $53^{\circ} \mathrm{F}$ (Stone et a1. 1983) is used for the outside ambient air. The energy loss to the atmosphere through the soil surface is modeled using a forced convective heat transfer coefficient of $2 \mathrm{Btu} /\left(\mathrm{h} \mathrm{ft}{ }^{2}{ }^{\circ} \mathrm{F}\right)$ (Bander 1992) at the ground surface, which is based on an average wind speed of $7.7 \mathrm{mi} / \mathrm{h}$ across the surface (Stone et al. 1983). An isothermal boundary of $55^{\circ} \mathrm{F}$ (Bander 1992) is employed at the water table $200 \mathrm{ft}$ below the ground surface. The axisymmetric model assumes an adiabatic boundary condition at the outer cylinder of the soil at a radius of $60 \mathrm{ft}$. The $75 \mathrm{ft}$ diameter tanks were built with a distance of $102 \mathrm{ft}$ between centers of tanks. The 60 ft radius provides more soil for heat absorption than a typical tank would have, thus a higher total heat source would be required to attain the temperatures inside the tank. This gives some conservatism to the thermal models used in estimating the total heat source.

A separate model was developed for each of the 10 tanks identified in Table 6 of SARR-010, which have heat loads estimated at or above 25,000 Btu/h. The major difference between models of tanks with in the same farm is the level of waste inside the tank. The heat source is assumed to be uniformiy distributed in the waste. The thermal properties of the various materials in the models are shown in Table 3.2.1. Since steady-state thermal solutions were obtained, only the thermal conductivity is relevant. The waste is assumed to have the thermal properties of water, since these analyses are based on limiting the temperature in the waste below the saturation temperature. This is conservative because the minerals in the waste will raise the saturation temperature above that of pure water. The variation of thermal conductivity with temperature of the water is included in the modeling.

\subsubsection{Tanks}

Tanks in the $C$ Tank Farm have one-half million gallon capacities with a dished bottom. Figure 3.3.2 shows the thermal model in the region of a $C$ tank. There are two $C$ tanks on the actively ventilated list having heat loads greater than or equal to $25,000 \mathrm{Btu} / \mathrm{h}, 241-\mathrm{C}-105$ and $241-\mathrm{C}-106$, both of which are not leakers. Tank 241-C-106 is scheduled to be sluiced the end of 1996. Therefore, no analyses were done for this tank, since its configuration will change. This tank will be analyzed when the sluicing is completed.

Tank 241-C-105 has not had any water added to it since early in 1993. Thus, it no longer has a water layer on top of the sludge. There is only one TC tree in the tank with four active TCs, in riser \#1, about $31 \mathrm{ft}$ from the center of the tank. The bottom two TCs are in the waste, one TC is slightly 
above the surface of the waste, and one TC is in the dome air-space, $16 \mathrm{ft}$ above the tank bottom.

\subsubsection{SX Tanks}

Tanks in the SX-Tank Farm have one million gallon capacities with a dished bottom. Figure 3.3 .3 shows the thermal model in the region of a $S X$ tank. Eight $S X$ tanks are on the actively ventilated list having heat loads greater than or equal to $25,000 \mathrm{Btu} / \mathrm{h}$, tanks 241-SX-103, 241-SX-107 through 241-SX-112, and 241-SX-114. A11 eight tanks, except tank 241-SX-103, are assumed to be leakers. There are eight TC trees in tanks 241-SX-107 through 241-SX-112 and 241-SX-114. However, only trees \#2 and \#8 are currently being regularly recorded. Tree \#2 is about $29 \mathrm{ft}$ from the center of the tank and tree \#8 is about $19 \mathrm{ft}$ from the center of the tank. The tank bottom at the location of trees \#2 and \#8 are $0.7 \mathrm{ft}$ and $0.3 \mathrm{ft}$ higher, respectively than the center of the tank. Although trees \#2 and \#8 are in different riser numbers for the different SX tanks, the radial and azimuthal locations are identical (A1stad 1993). Five years of temperature data were averaged to obtain the temperature distributions for TC trees \#2 and \#8 of each tank. Tank 241-SX-103 has only one TC tree, which is in riser \#2, about $15 \mathrm{ft}$ from the center of the tank.

The waste levels in tanks 241-SX-107, 241-SX-108, 241-SX-110, 241-5X-111, and 241-SX-112 are low enough that TCS at the top of the trees are in the tank air-space. Tank $241-S X-103$ has one TC in the tank air-space. For tanks 241-SX-109 and 241-SX-114 al1 of the TCS are below the waste surface. 
Figure 3.3.1. Entire Thermal Model for One million gal Single-Shell Tank.

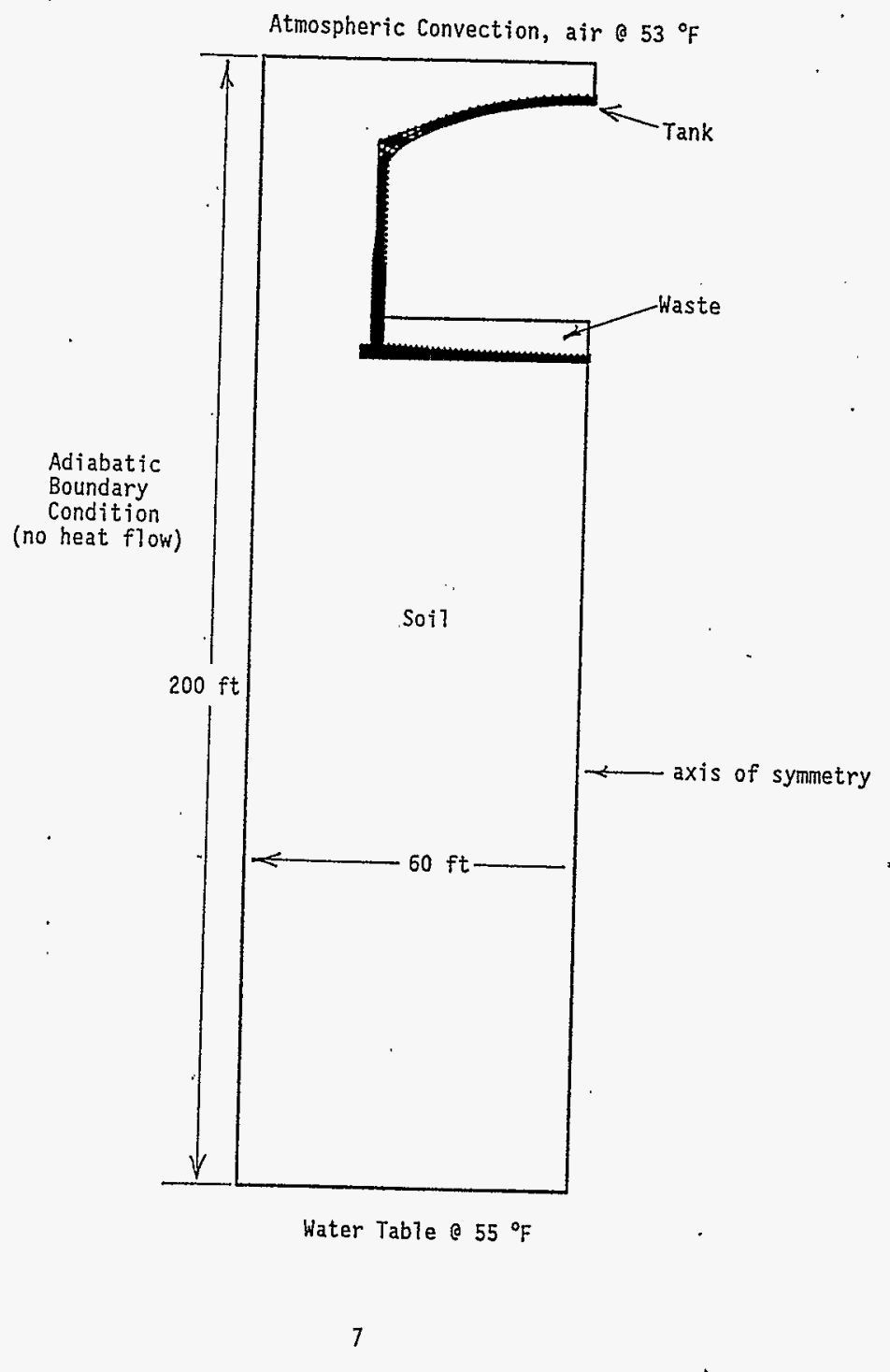


WHC-SD-WM-ER-620, Rev. 0

Figure 3.3.2. C-Tank Thermal Mode1.

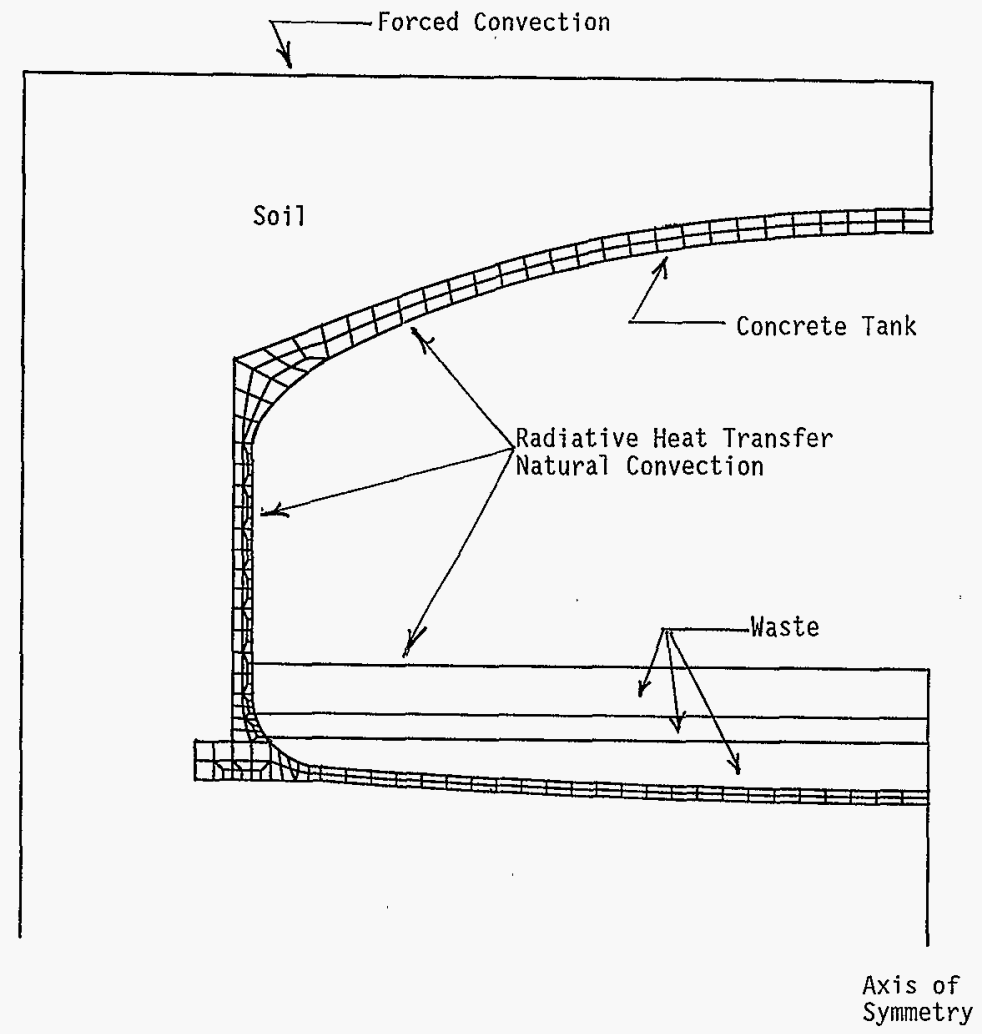


WHC-SD-WM-ER-620, Rev. 0

Figure 3.3.3. SX-Tank Thermal Mode1.

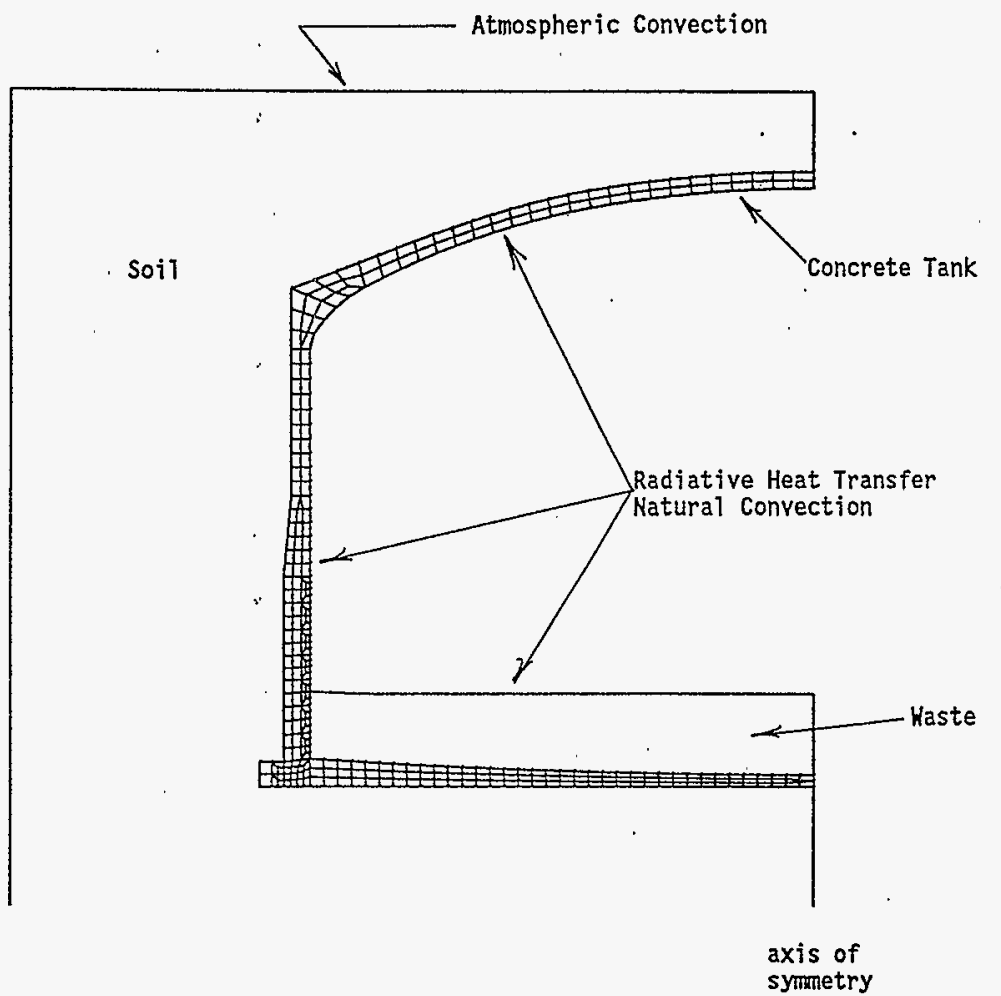


WHC-SD-WM-ER-620, Rev. 0

\subsection{ANALYTICAL METHOD}

\subsection{DOUBLE-SHELL TANKS}

The results presented in Section 5 are all derived by adjusting the heating rate in the waste until the maximum waste temperature is at saturation for the depth of waste being modeled. This temperature is a function of the type of waste material and the waste depth. As a conservative estimate, the waste material properties are assumed to be that of pure water. Therefore, the saturation temperature will only vary as a function of the depth below the waste surface at which the maximum temperature occurs. The flows and boundary condition temperatures are all chosen to provide a realistic maximum temperature gradient in the waste.

The different DST models were all analyzed based on the assumption that any supernate was isotherma?. Inherent in this approach is the assumption that a well defined sludge layer exists and that a majority of the decay heat production occurs in this sludge layer. This approach is conservative, since if the waste isn't quiescent then convective forces will act to reduce any temperature differences.

There may be major differences between tank designs in some aspects of DST construction. However, when the airlift circulators are inactive and there is a settled layer of sludge in the bottom a11 DSTs look the same from a thermal standpoint. Since the level of waste in DSTs can change as a result of ongoing processes, such as saltwell pumping or sluicing type retrieval operations a parametric approach was taken to defining the temperature offset for a DST. Analyses were done for seven different levels of sludge in a tank and the results were then tabulated for each of these sludge levels and at representative radiat thermocouple tree locations.

\subsection{SINGLE-SHELL TANKS}

The limiting temperatures in the waste for these analyses are based on holding the maximum temperature in the waste at the saturation temperature. This temperature is a function of the type of waste material and the waste depth. As a conservative estimate, the waste material properties are assumed to be that of pure water. Therefore, the saturation temperature will only vary as a function of the depth below the waste surface at which the maximum temperature occurs.

Three different ventilation rates were used in the analyses: to represent passive, nominal, and high rates of flow through the tanks. The flow measurements taken from these tanks vary significantly over time (factors of 2 or 3). Al1 the tanks except tank 241-SX-103 were analyzed with 5 scfm (this represents passive ventilation), $500 \mathrm{scfm}$, and $1000 \mathrm{scfm}$ flowrates. Tank 241-SX-103 was analyzed with flowrates of $5 \mathrm{scfm}, 100 \mathrm{scfm}$, and $200 \mathrm{scfm}$. The flowrates were reduced for tank 241-SX-103, because it is one of six tanks which flow into tank 241-SX-109. 


\subsection{RESULTS OF ANALYSES}

\subsection{DOUBLE-SHELL TANKS}

The difference between the maximum temperature for a model with a sludge depth as shown in Table 5.1.1 and the temperature at a specific radial and vertical location is defined as the temperature offset. The results presented in Tables 5.1.2 to 5.1.8 represent the temperature offset due to the thermocouple radial location and elevation above the tank bottom for discrete sludge depths of $2,6,12,18,24,30$, and 36 feet. As an example

Figure 5.1.1 shows the offset profiles for the case with 24 feet of siudge in the tank.

Table 5.1.1 shows the saturation temperature in the tank for the various. sludge depths considered, provided that the tank contains on Ty sludge. Most waste tanks have a supernate layer above the sludge layer. The supernate layer is considered to be isothermal, and so the main effect of it is to raise the hydrostatic head and hence the saturation temperature in the sludge. A conservative approximation to the increase of saturation temperature with respect to depth of supernate is $1: 15^{\circ} \mathrm{F} / \mathrm{ft}$.

The following example clarifies this point:

If a tank contains 12 feet of sludge and 15 feet of supernate the saturation temperature at the hottest point in the tank is:

$$
\begin{aligned}
220+1.15 \times 15=237.25^{\circ} \mathrm{F} \quad \begin{array}{l}
\text { (from Table } 5.1 .1 \text { and the temperature } \\
\text { increase rate given above) }
\end{array}
\end{aligned}
$$

Now determine the temperature setpoint for a TC located $8 \mathrm{ft}$ above the tank center bottom and at $20 \mathrm{ft}$ from the center of the tank. From Table 5.1.4 (the table for 12 feet of sludge) the offset for this location is $21^{\circ} \mathrm{F}$. The temperature indication from this TC would then be:

$$
237.25-21=216.25^{\circ} \mathrm{F}
$$

when the hottest point in the tank was at saturation. The "alarm setpoint" should then be set at $216^{\circ} \mathrm{F}$ - (appropriate margin).

Table 5.1.1. Saturation Temperature as a Function of S1udge Depth.

\begin{tabular}{|c|c|}
\hline Sludge Depth (ft) & Saturation Temperature $\left({ }^{\circ} \mathrm{F}\right)$ \\
\hline 2 & 213 \\
\hline 6 & 216 \\
\hline 12 & 220 \\
\hline 18 & 224 \\
\hline 24 & 228 \\
\hline 30 & 231 \\
\hline 36 & 234 \\
\hline
\end{tabular}


Table 5.1.2. Thermocouple Offset from Saturation $\left(F^{\circ}\right)$ for $2 \mathrm{ft}$ of Sludge.

\begin{tabular}{|c|c|c|c|c|}
\hline & \multicolumn{4}{|c|}{ Thermocouple Tree Distance from Center (ft) } \\
\hline $\begin{array}{c}\text { Feet above tank bottom } \\
\text { at tank center }\end{array}$ & 10 & 20 & 28 & $34 \mathrm{ft}-9$ in. \\
\hline \hline 2 & 108 & 110 & 116 & 123 \\
\hline
\end{tabular}

Table 5.1.3. Thermocouple offset from Saturation $\left(F^{\circ}\right)$ for 6 Ft of Sludge.

\begin{tabular}{|c|c|c|c|c|}
\hline & \multicolumn{4}{|c|}{ Thermocouple Tree Distance from Center (ft) } \\
\hline $\begin{array}{c}\text { Feet above tank bottom } \\
\text { at tank center }\end{array}$ & 10 & 20 & 28 & $34 \mathrm{ft}-9$ in. \\
\hline \hline 2 & 16 & 15 & 24 & 85 \\
\hline 4 & 14 & 27 & 42 & 107 \\
\hline
\end{tabular}

Table 5.1.4. Thermocouple offset from Saturation $\left(F^{\circ}\right)$ for $12 \mathrm{ft}$ of STudge.

\begin{tabular}{|c|c|c|c|c|}
\hline & \multicolumn{4}{|c|}{ Thermocouple Tree Distance from Center (ft) } \\
\hline $\begin{array}{c}\text { Feet above tank bottom } \\
\text { at tank center }\end{array}$ & 10 & 20 & 28 & $34 \mathrm{ft}-9 \mathrm{in}$. \\
\hline \hline 2 & 60 & 69 & 85 & 129 \\
\hline 4 & 16 & 23 & 40 & 101 \\
\hline 6 & 2 & 7 & 24 & 92 \\
\hline 8 & 17 & 21 & 35 & 95 \\
\hline 10 & 64 & 66 & 77 & 112 \\
\hline
\end{tabular}


WHC-SD-WM-ER-620, Rev. 0

Table 5.1.5. Thermocouple offset from Saturation $\left(F^{\circ}\right)$ for $18 \mathrm{ft}$ of Sludge.

\begin{tabular}{|c|c|c|c|c||}
\hline & \multicolumn{4}{|c|}{ Thermocouple Tree Distance from Center (ft) } \\
\hline $\begin{array}{c}\text { Feet above tank bottom } \\
\text { at tank center }\end{array}$ & 10 & 20 & 28 & $34 \mathrm{ft}-9$ in. \\
\hline \hline 2 & 93 & 99 & 118 & 151 \\
\hline 4 & 49 & 56 & 80 & 130 \\
\hline 6 & 19 & 27 & 55 & 119 \\
\hline 8 & 5 & 15 & 42 & 112 \\
\hline 10 & 4 & 14 & 40 & 110 \\
\hline 12 & 19 & 27 & 50 & 114 \\
\hline 14 & 48 & 54 & 71 & 123 \\
\hline 16 & 93 & 96 & 106 & 130 \\
\hline
\end{tabular}

Table 5.1.6. Thermocouple offset from Saturation $\left(F^{\circ}\right)$ for $24 \mathrm{ft}$ of Sludge.

\begin{tabular}{|c|c|c|c|c||}
\hline & \multicolumn{4}{|c|}{ Thermocouple Tree Distance from Center (ft) } \\
\hline $\begin{array}{c}\text { Feet above tank bottom } \\
\text { at tank center }\end{array}$ & 10 & 20 & 28 & $34 \mathrm{ft}-9$ in. \\
\hline \hline 2 & 114 & 123 & 138 & 165 \\
\hline 4 & 73 & 85 & 106 & 148 \\
\hline 6 & 43 & 57 & 84 & 140 \\
\hline 8 & 21 & 37 & 68 & 132 \\
\hline 10 & 9 & 25 & 58 & 127 \\
\hline 12 & 5 & 20 & 55 & 124 \\
\hline 14 & 9 & 24 & 57 & 125 \\
\hline 16 & 21 & 35 & 65 & 127 \\
\hline 18 & 43 & 54 & 79 & 132 \\
\hline 20 & 74 & 82 & 100 & 140 \\
\hline 22 & 115 & 119 & 129 & 152 \\
\hline
\end{tabular}


Table 5.1.5. Thermocouple offset from Saturation $\left(F^{\circ}\right)$ for $18 \mathrm{ft}$ of Sludge.

\begin{tabular}{|c|c|c|c|c||}
\hline & \multicolumn{4}{|c|}{ Thermocouple Tree Distance from Center (ft) } \\
\hline $\begin{array}{c}\text { Feet above tank bottom } \\
\text { at tank center }\end{array}$ & 10 & 20 & 28 & $34 \mathrm{ft}-9 \mathrm{in}$. \\
\hline \hline 2 & 93 & 99 & 118 & 151 \\
\hline 4 & 49 & 56 & 80 & 130 \\
\hline 6 & 19 & 27 & 55 & 119 \\
\hline 8 & 5 & 15 & 42 & 112 \\
\hline 10 & 4 & 14 & 40 & 110 \\
\hline 12 & 19 & 27 & 50 & 114 \\
\hline 14 & 48 & 54 & 71 & 123 \\
\hline 16 & 93 & 96 & 106 & 130 \\
\hline
\end{tabular}

Table 5.1.6. Thermocouple offset from Saturation $\left(F^{\circ}\right)$ for $24 \mathrm{ft}$ of Sludge.

\begin{tabular}{|c|c|c|c|c||}
\hline & \multicolumn{4}{|c|}{ Thermocouple Tree Distance from Center (ft) } \\
\hline $\begin{array}{c}\text { Feet above tank bottom } \\
\text { at tank center }\end{array}$ & 10 & 20 & 28 & $34 \mathrm{ft}-9$ in. \\
\hline 2 & 114 & 123 & 138 & 165 \\
\hline 4 & 73 & 85 & 106 & 148 \\
\hline 6 & 43 & 57 & 84 & 140 \\
\hline 8 & 21 & 37 & 68 & 132 \\
\hline 10 & 9 & 25 & 58 & 127 \\
\hline 12 & 5 & 20 & 55 & 124 \\
\hline 14 & 9 & 24 & 57 & 125 \\
\hline 16 & 21 & 35 & 65 & 127 \\
\hline 18 & 43 & 54 & 79 & 132 \\
\hline 20 & 74 & 82 & 100 & 140 \\
\hline 22 & 115 & 119 & 129 & 152 \\
\hline
\end{tabular}


WHC-SD-WM-ER-620, Rev. 0

Table 5.1.8. Thermocouple offset from Saturation $\left(F^{\circ}\right)$ for $36 \mathrm{ft}$ of sludge.

\begin{tabular}{|c|c|c|c|c|}
\hline & \multicolumn{4}{|c|}{ Thermocouple Tree Distance from Center (ft) } \\
\hline $\begin{array}{l}\text { Feet above tank bottom } \\
\text { at tank center }\end{array}$ & 10 & 20 & 28 & $34 \mathrm{ft}-9$ in. \\
\hline 2 & 143 & 152 & 165 & 184 \\
\hline 4 & 111 & 123 & 142 & 172 \\
\hline 6 & 82 & 98 & 124 & 165 \\
\hline 8 & 58 & 78 & 107 & 158 \\
\hline 10 & 41 & 62 & 97 & 153 \\
\hline 12 & 26 & 49 & 87 & 149 \\
\hline 14 & 16 & 41 & 83 & 146 \\
\hline 16 & 10 & 36 & 79 & 144 \\
\hline 18 & 8 & 34 & 78 & 143 \\
\hline 20 & 10 & 35 & 79 & 142 \\
\hline 22 & 16 & 40 & 82 & 143 \\
\hline 24 & 26 & 48 & 87 & 144 \\
\hline 26 & 39 & 59 & 95 & 147 \\
\hline 28 & 58 & 75 & 106 & 150 \\
\hline 30 & 82 & 97 & 121 & 155 \\
\hline 32 & 109 & 119 & 139 & 162 \\
\hline 34 & 144 & 149 & 159 & 172 \\
\hline
\end{tabular}




\section{DST WITH 24 FEET OF SLUDGE}

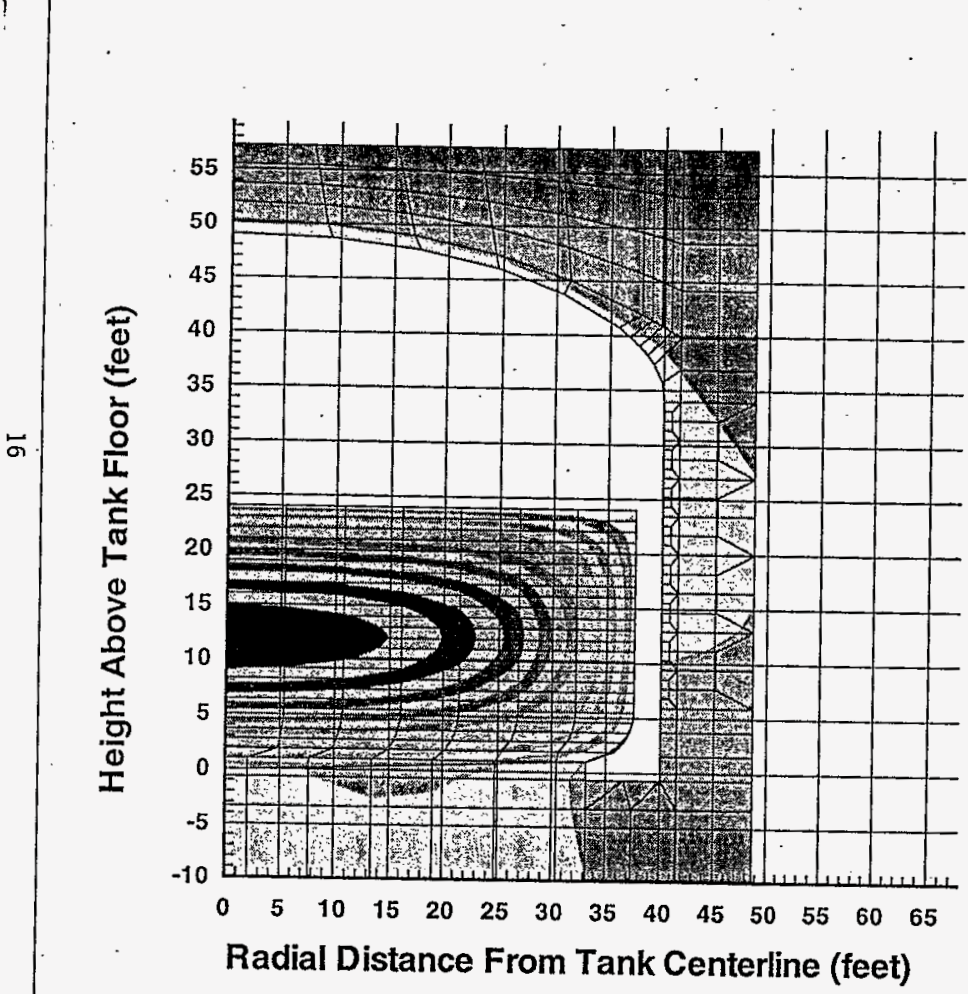

Thermocouple Offset From Maximum deg-F

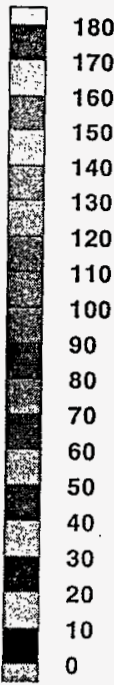




\subsection{SINGLE-SHELL TANKS}

The results for single-shell tanks (SST) were obtained by maintaining the maximum calculated temperature at or below the local saturation temperature. Tank 241-C-105 contains about $4.5 \mathrm{ft}$ of sludge in the center of the tank. The maximum temperature occurs about $1 / 2 \mathrm{ft}$ from the bottom of the tank. The saturation temperature at this location is about $218^{\circ} \mathrm{F}$. Figure 5.2 .1 shows the calculated temperatures for the three cases described in Section 4.2. The case with the lowest calculated temperatures at the TC tree location is for passive ventilation. This figure shows that for all ventilation rates the measured temperatures are more than $85{ }^{\circ} \mathrm{F}$ below the temperature that would be measured if the maximum temperature in the tank was at the saturation temperature. This indicates that the sludge in this tank is nowhere near the saturation temperature.

Tank 241-SX-103 contains almost $20 \mathrm{ft}$ of s7udge in the center of the tank. The maximum temperature occurs about $4 \mathrm{ft}$ from the bottom of the tank. The saturation temperature at this location is about $232^{\circ} \mathrm{F}$. Figure 5.2.2 shows the calculated temperatures for the three cases described in Section 4.2. Due to The lower ventilation rates (passive, $100 \mathrm{scfm}$, and $200 \mathrm{scfm}$ ) and the large depth of the sludge in this tank all three cases have very similar calculated temperatures at the TC tree location. This figure shows that the measured temperatures are more than $45^{\circ} \mathrm{F}$ below the temperature that would be measured if the maximum temperature in the tank was at the saturation temperature. This indicates that the siudge in this tank is nowhere near the saturation temperature.

Tank 241-SX-107 contains almost $3.5 \mathrm{ft}$ of sludge in the center of the tank. The maximum temperature occurs about $1 / 2 \mathrm{ft}$ from the bottom of the tank. The saturation temperature at this location is about $216^{\circ} \mathrm{F}$. Figure 5.2.3 shows the calculated temperatures for the three cases described in Section 4.2 at the two TC tree locations. The temperatures at the TC tree $29 \mathrm{ft}$ from the center of the tank have average measured temperatures higher than those at the TC tree $19 \mathrm{ft}$ from the center of the tank. This is opposite to what would occur if the heat concentration and thermal conductivities were uniform. The calculated temperatures are still lower for all cases when considering the maximum measured temperatures. This figure shows that the measured temperatures are close to the calculated temperatures for the TC tree $29 \mathrm{ft}$ from the center of the tank for passive ventilation. For the TC tree $19 \mathrm{ft}$ from the center of the tank the calculated temperatures are at least $30^{\circ} \mathrm{F}$ below the temperatures that would be measured if the maximum temperature in the tank was at the saturation temperature.

Tank 241-SX-108 contains almost $3 \mathrm{ft}$ of sludge in the center of the tank. The maximum temperature occurs at the bottom of the tank. The saturation temperature at this location is about $216^{\circ} \mathrm{F}$. Figure 5.2 .4 shows the calculated temperatures for the three cases described in Section 4.2 at the two TC tree locations. The average measured temperature at the bottom TC of the TC tree located $29 \mathrm{ft}$ from the center of the tank is higher than that at the TC tree $19 \mathrm{ft}$ from the center of the tank. This is opposite to what would occur if the heat concentration and thermal conductivities were uniform. The calculated temperatures are lower than the maximum measured temperatures for the passive and $500 \mathrm{scfm}$ ventilation cases. A recent core sample from this tank shows that the sludge is very dry. Therefore "bumping" in this tank 
WHC-SD-WM-ER-620, Rev. 0

cannot occur. The measured temperatures are below the structural 7 imit requirements.

Tank 241-SX-109 contains almost $8 \mathrm{ft}$ of sludge in the center of the tank. The maximum temperature occurs about $1.5 \mathrm{ft}$ from the bottom of the tank. The saturation temperature at this location is about $221^{\circ} \mathrm{F}$. Figure 5.2 .5 shows the calculated temperatures for the three cases described in Section 4.2 at the two TC tree locations. This figure shows that the measured temperatures are more than $40^{\circ} \mathrm{F}$ below the temperatures that would be measured if the maximum temperature in the tank was at the saturation temperature.

Tank 241-SX-110 contains little a more than $2 \mathrm{ft}$ of sludge in the center of the tank. The maximum temperature occurs at the bottom of the tank. The saturation temperature at this location is about $215^{\circ} \mathrm{F}$. Figure 5.2 .6 shows the calculated temperatures for the three cases described in Section 4.2 at the two TC tree locations. The temperatures at the TC tree $29 \mathrm{ft}$ from the center of the tank have average measured temperatures higher than those at the TC tree $19 \mathrm{ft}$ from the center of the tank. This is opposite to what would occur if the heat concentration and thermal conductivities were uniform. The calculated temperatures at the TC tree $29 \mathrm{ft}$ from the center of the tank are lower than the maximum measured temperatures for the passive and $500 \mathrm{scfm}$ ventilation cases. The measured temperatures at the TC tree $19 \mathrm{ft}$ from the center of the tank are about $20^{\circ} \mathrm{F}$ below the temperatures that would be measured if the maximum temperature in the tank was at the saturation temperature.

Tank 241-5X-111 contains a 1ittle more than $4 \mathrm{ft}$ of sludge in the center of the tank. The maximum temperature occurs at about $1 / 2 \mathrm{ft}$ from the bottom of the tank. The saturation temperature at this location is about $217{ }^{\circ} \mathrm{F}$. Figure 5.2.7 shows the calculated temperatures for the three cases described in Section 4.2 at the two TC tree locations. The temperatures at the TC tree $29 \mathrm{ft}$ from the center of the tank have average measured temperatures higher than those at the TC tree $19 \mathrm{ft}$ from the center of the tank. This is opposite to what would occur if the heat concentration and thermal conductivities were uniform. The calculated. temperatures at the TC tree $29 \mathrm{ft}$ from the center of the tank are lower than the maximum measured temperatures for the passive and $500 \mathrm{scfm}$ ventilation cases. The measured temperatures at the TC tree $19 \mathrm{ft}$ from the center of the tank are about $40^{\circ} \mathrm{F}$ below the temperatures that would be measured if the maximum temperature in the tank was at the saturation temperature.

Tank 241-SX-112 contains almost $3 \mathrm{ft}$ of sludge in the center of the tank. The maximum temperature occurs at the bottom of the tank. The saturation temperature at this location is about $216^{\circ} \mathrm{F}$. Figure 5.2 .8 shows the calculated temperatures for the three cases described in Section 4.2 at the two TC tree locations. This figure shows that the measured temperatures are 20 to $40^{\circ} \mathrm{F}$ below the temperatures that would be measured if the maximum temperature in the tank was at the saturation temperature.

Tank 241-SX-114 contains about $5.5 \mathrm{ft}$ of sludge in the center of the tank. The maximum temperature occurs at about $1 / 2 \mathrm{ft}$ from the bottom of the tank. The saturation temperature at this location is about $219^{\circ} \mathrm{F}$. Figure 5.2.9 shows the calculated temperatures for the three cases described in Section 4.2 at the two TC tree locations. The temperatures at the TC tree 
$29 \mathrm{ft}$ from the center of the tank have average measured temperatures higher than those at the TC tree $19 \mathrm{ft}$ from the center of the tank. This is opposite to what would occur if the heat concentration and thermal conductivities were uniform. The calculated temperatures at the TC tree $29 \mathrm{ft}$ from the center of the tank are close to the maximum measured temperatures for the passive and $500 \mathrm{scfm}$ ventilation cases. The measured temperatures at the TC tree $19 \mathrm{ft}$ from the center of the tank are more than $20^{\circ} \mathrm{F}$ below the temperatures that would be measured if the maximum temperature in the tank was at the saturation temperature. 
Tables 5.2.1 and 5.2.2 summarize the results of this section.

Table 5.2.1 gives the temperature differences between the calculated and measured temperatures for the TC location which has the highest measured temperature. This table gives an indication of the amount of margin that is currently available in these tanks. The most conservative margin would be for the ventilation rate of $1000 \mathrm{scfm}(200 \mathrm{scfm}$ for tank 241-SX-103).

Table 5.2.1. Temperature Difference between Calculated and Measured Temperatures at TC Tree Locations for Saturation Temperature at Center of Tank.

\begin{tabular}{|c|c|c|c|c|c|}
\hline \multirow[t]{2}{*}{$\begin{array}{l}\text { Tank/TC tree } \\
\text { Distance } \\
\text { from center } \\
\text { (ft) }\end{array}$} & \multirow[t]{2}{*}{$\begin{array}{l}\text { STudge } \\
\text { Depth at } \\
\text { center of } \\
\text { tank } \\
\text { (ft) }\end{array}$} & \multirow[t]{2}{*}{$\begin{array}{c}\text { Saturation } \\
\text { Temperature } \\
\left({ }^{\circ} \mathrm{F}\right)\end{array}$} & \multicolumn{3}{|c|}{$\begin{array}{c}\text { Temperature Difference } \\
\text { (negative value denotes higher } \\
\text { than calculated) } \\
\left({ }^{\circ} \mathrm{F}\right)\end{array}$} \\
\hline & & & Passive & $500 \mathrm{scfm}$ & $1000 \mathrm{scfm}$ \\
\hline$C-105 / 31$ & 4.6 & 218 & 111 & 94 & 87 \\
\hline $5 X-103 / 15$ & 19.7 & 232 & 47 & $\left(100^{46} \mathrm{scfm}\right)$ & $\left(200^{46} \mathrm{scfm}\right)$ \\
\hline$S X-107 / 19$ & 3.4 & 216 & 39 & 33 & 30 \\
\hline $5 \times-107 / 29$ & 3.4 & 216 & 27 & 13 & 6 \\
\hline$S X-108 / 19$ & 2.7 & 216 & 9 & 0 & -4 \\
\hline$S X-108 / 29$ & 2.7 & 216 & 4 & -14 & -24 \\
\hline$S X-109 / 19$ & 7.9 & 221 & 65 & 61 & 59 \\
\hline$S X-109 / 29$ & 7.9 & 221 & 57 & 47 & 42 \\
\hline$S X-110 / 19$ & 2.2 & 215 & 36 & 25 & 18 \\
\hline$S X-110 / 29$ & 2.2 & 215 & 20 & -1 & -13 \\
\hline$S X-111 / 19$ & 4.1 & 217 & 47 & 41 & 39 \\
\hline$S X-111 / 29$ & 4.1 & 217 & 10 & -3 & -9 \\
\hline$S X-112 / 19$ & 2.9 & 216 & 49 & 42 & 39 \\
\hline$S X-112 / 29$ & 2.9 & 216 & 45 & 30 & 21 \\
\hline$s x-114 / 19$ & 5.5 & 219 & 28 & 23 & 21 \\
\hline$S X-114 / 29$ & 5.5 & 219 & 13 & 2 & -2 \\
\hline
\end{tabular}


Table 5.2.2 gives the temperature of the calculated steady-state analyses for the different ventilation rates. Also included are the average measured temperatures for the TC location which has the highest measured temperature. The seasonal variation on the average temperatures is at most $+/-10^{\circ} \mathrm{F}$.

Table 5.2.2. Temperatures of Calculated and Measured Temperatures at TC Tree Locations for Saturation Temperature at Center of Tank.

\begin{tabular}{|c|c|c|c|c|c|}
\hline \multirow{2}{*}{$\begin{array}{c}\text { Tank/TC tree } \\
\text { Distance from } \\
\text { center } \\
(\mathrm{ft})\end{array}$} & \multirow{2}{*}{$\begin{array}{c}\text { Sludge } \\
\text { Depth at } \\
\text { center of } \\
\text { tank } \\
(\mathrm{ft})\end{array}$} & \multirow{2}{*}{$\begin{array}{c}\text { Average } \\
\text { Measured } \\
\text { Temperature } \\
\left({ }^{\circ} \mathrm{F}\right)\end{array}$} & \multicolumn{3}{|c|}{$\begin{array}{c}\text { Calculated Temperature } \\
\left({ }^{\circ} \mathrm{F}\right)\end{array}$} \\
\hline & & & Passive & $500 \mathrm{scfm}$ & $1000 \mathrm{scfm}$ \\
\hline$C-105 / 31$ & 4.6 & 89 & 200 & 184 & 176 \\
\hline$S X-103 / 15$ & 19.7 & 176 & 223 & $\left(100^{222} \mathrm{scfm}\right)$ & $\left(200^{222} \mathrm{scfm}\right)$ \\
\hline$S X-107 / 19$ & 3.4 & 170 & 208 & 202 & 200 \\
\hline$S X-107 / 29$ & 3.4 & 172 & 199 & 185 & 178 \\
\hline$S X-108 / 19$ & 2.7 & 198 & 207 & 198 & 194 \\
\hline$S X-108 / 29$ & 2.7 & 193 & 197 & 179 & 170 \\
\hline$S X-109 / 19$ & 7.9 & 150 & 214 & 210 & 209 \\
\hline$S x-109 / 29$ & 7.9 & 146 & 203 & 193 & 189 \\
\hline $5 X-110 / 19$ & 2.2 & 168 & 204 & 192 & 186 \\
\hline$S X-110 / 29$ & 2.2 & 174 & 194 & 173 & 161 \\
\hline $5 X-111 / 19$ & 4.1 & 163 & 209 & 204 & 202 \\
\hline$S X-111 / 29$ & 4.1 & 190 & 200 & 187 & 181 \\
\hline$S X-112 / 19$ & 2.9 & 158 & 207 & 200 & 196 \\
\hline$S X-112 / 29$ & 2.9 & 152 & 198 & 182 & 173 \\
\hline $5 X-114 / 19$ & 5.5 & 184 & 211 & 207 & 205 \\
\hline$S X-114 / 29$ & 5.5 & 187 & 200 & 189 & 185 \\
\hline
\end{tabular}

Tanks 241-C-105 and 241-SX-103 have temperatures reported by the singie TC tree in these tanks which are significantly below the calculated temperatures for a11 ventilation rates assumed. The SSTs 241-SX-107, 241-SX-109 through 241-SX-112, and 241-SX-114 have temperatures reported by the TC tree $19 \mathrm{ft}$ from the center of the tank which are about $20^{\circ} \mathrm{F}$ or more below the calculated temperatures for all ventilation rates assumed. Tank 241-SX-108 has temperatures reported by the TC trees which are above or close to the calculated temperatures. However, this tank has been recently sampled 
and the sludge is very dry, therefore temperatures above saturation are not an issue.

The TC tree $29 \mathrm{ft}$ from the center of the tank for SSTs 241-SX-107, 241-SX-110, 241-SX-111, and 241-SX-114 have temperatures reported by the TC tree which are above or close to the calculated temperatures. Some temperature margin should also be applied to the calculated temperatures to account for assumptions made in the modeling. It is not known if these tanks are completely dry. A sludge sample from these tanks would provide the information to determine the need for further evaluation of these tanks. 
WHC-SD-WM-ER-620, Rev. 0

Figure 5.2.1. Tank 241-C-105 Temperatures: Measured and Calculated.

Temperatures: TC tree in riser \#1 (31 ft from center of tank)

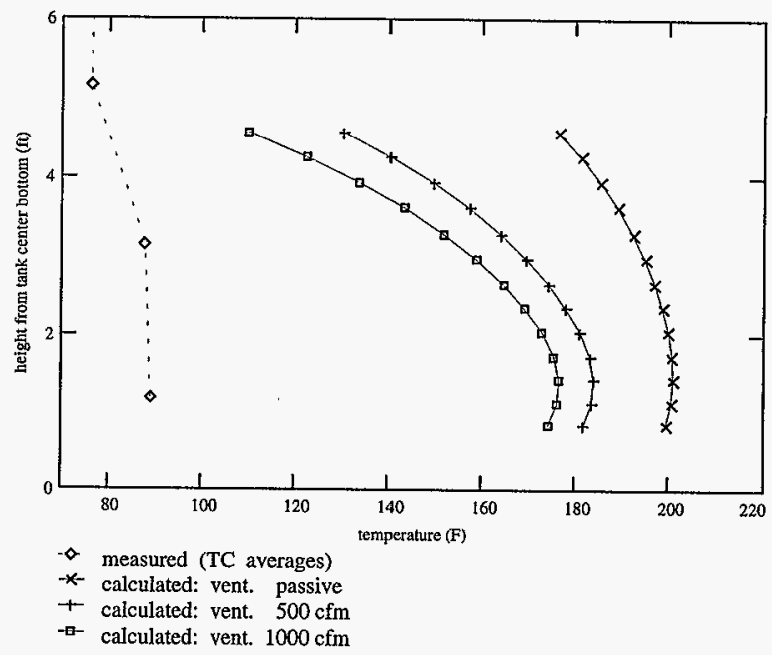

Temperatures: center of tank

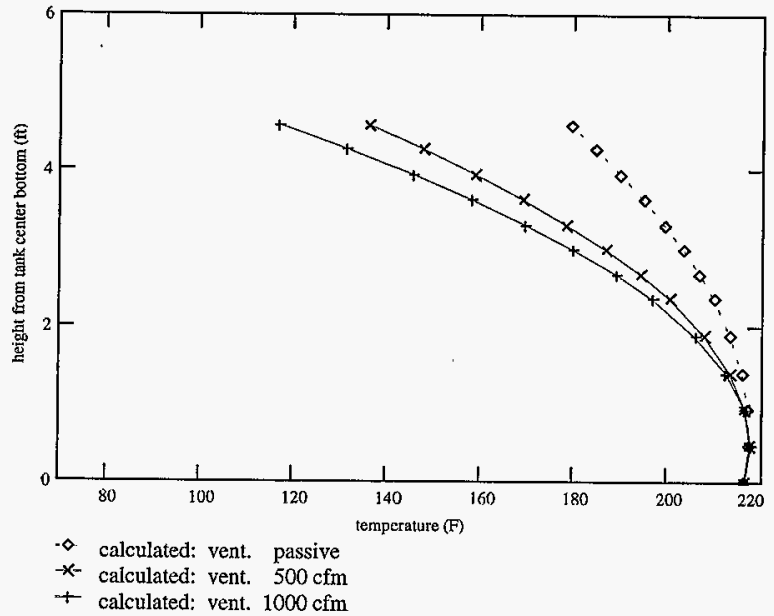


Figure 5.2.2. Tank 241-SX-103 Temperatures: Measured and Calculated. Temperatures: TC tree in riser $\$ 2$ (15 ft from center of tank)

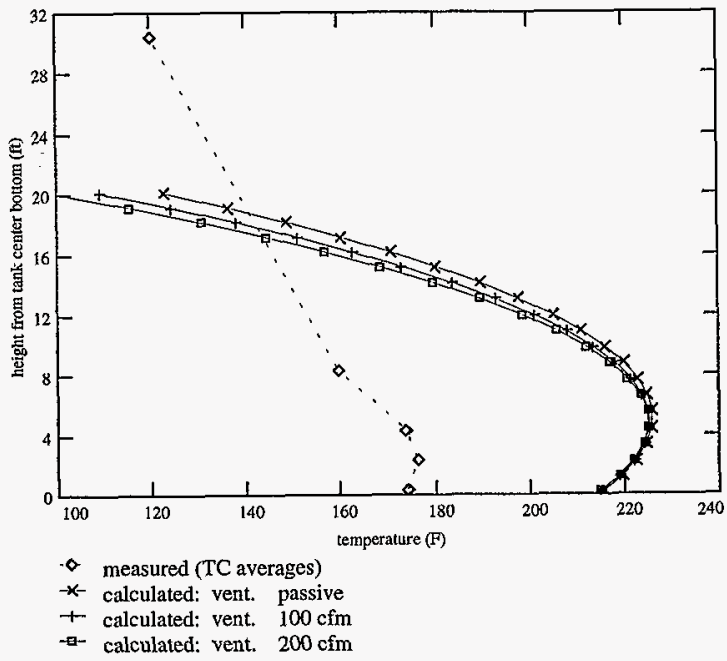

Temperatures: center of tank

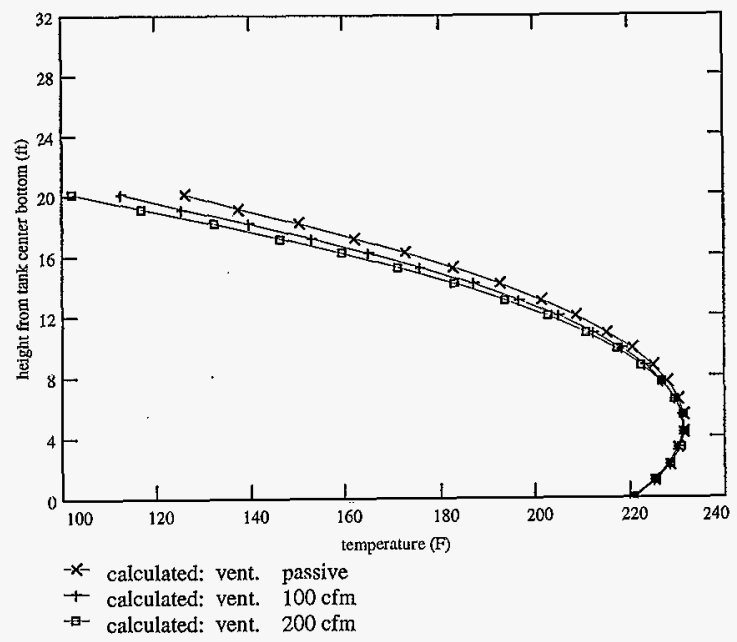


Figure 5.2.3. Tank 241-SX-107 Temperatures: Measured and Calculated. Temperatures: $T C$ tree in riser \#10 (29 $\mathrm{ft}$ from center of tank)

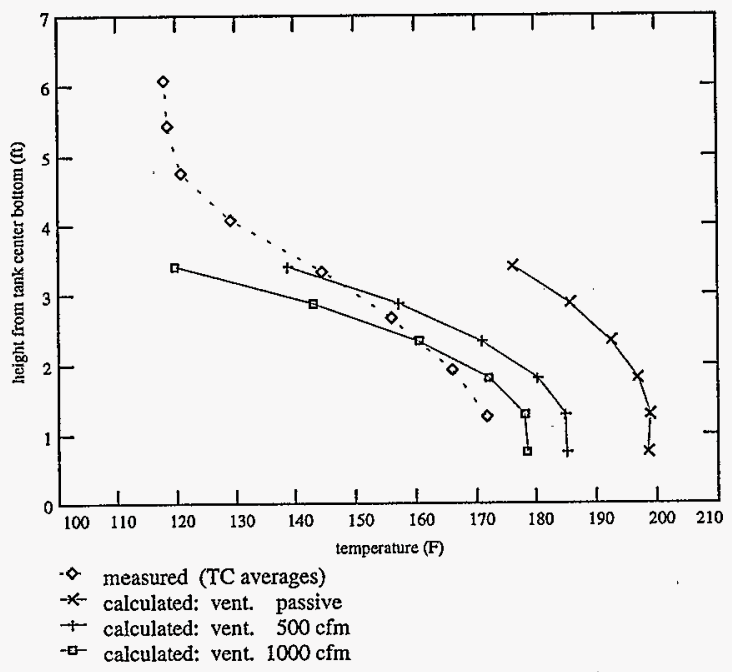

Temperatures: TC tree in riser \#14 (19 ft from center of tank)

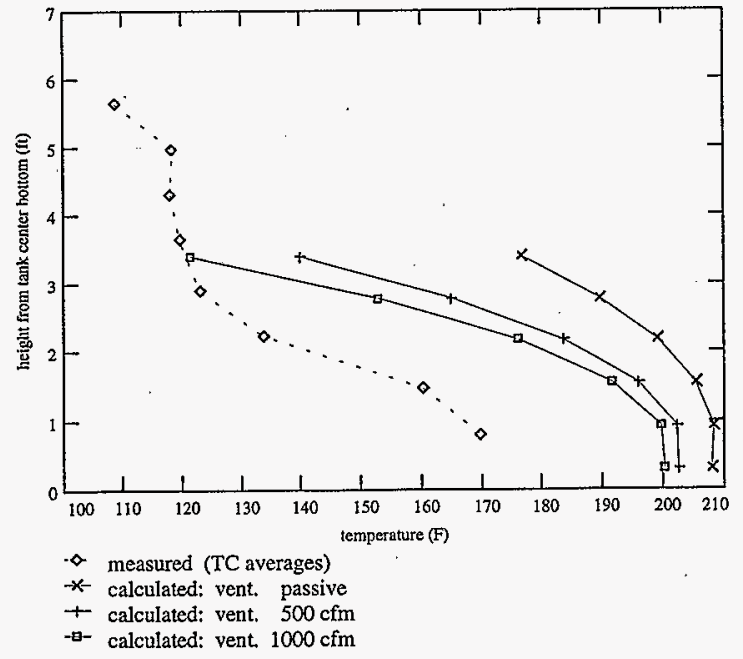


Figure 5.2.4. Tank 241-SX-108 Temperatures: Measured and Calculated. Temperatures: TC tree in riser \#10 (29ft from center of tank)

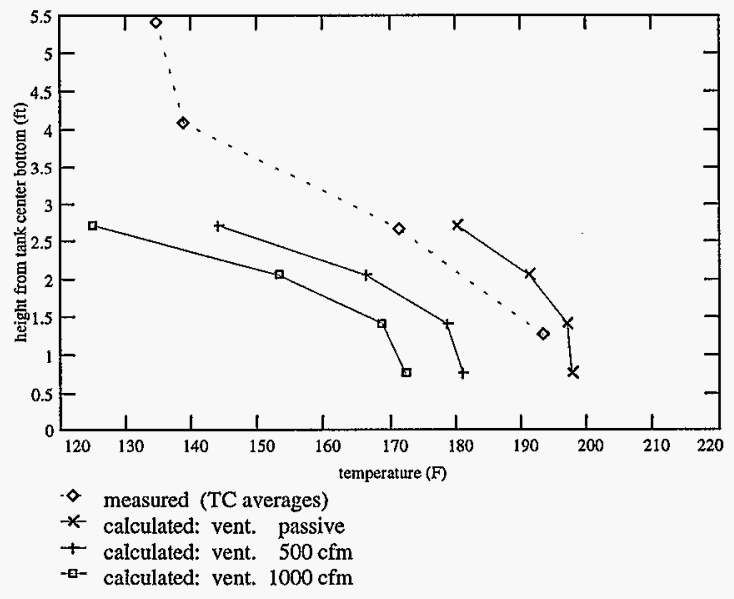

Temperatures: TC tree in riser \#19 (19 ft from center of tank)

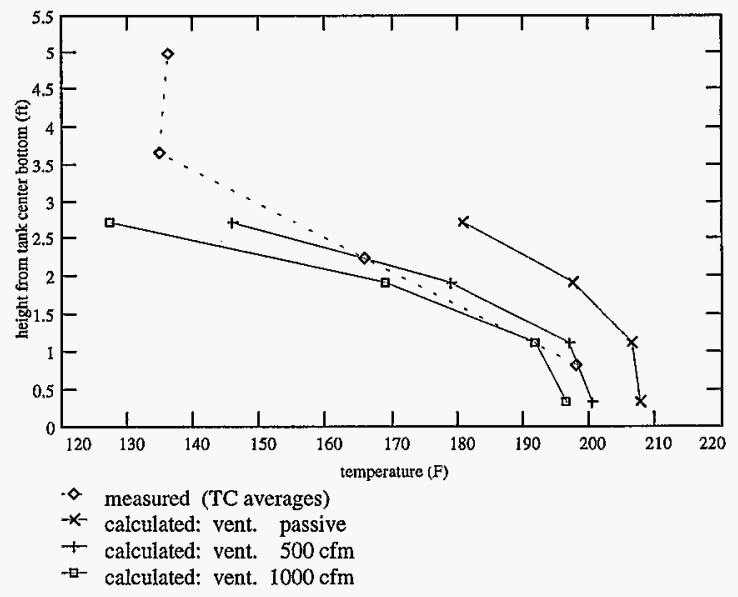


Figure 5.2.5. Tank 241-SX-109 Temperatures: Measured and Calculated. Temperatures: TC tree in riser \#10 ( $29 \mathrm{ft}$ from center of tank)

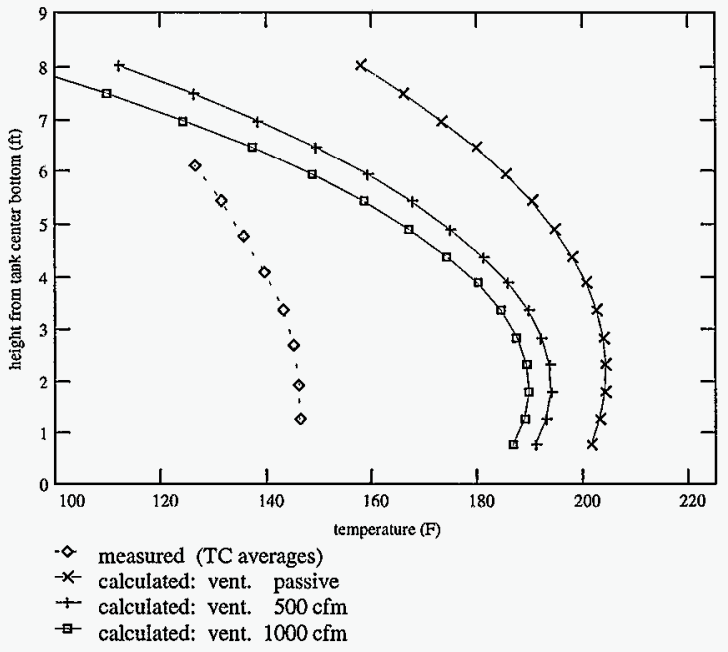

Temperatures: TC tree in riser \#19 (19 ft from center of tank)

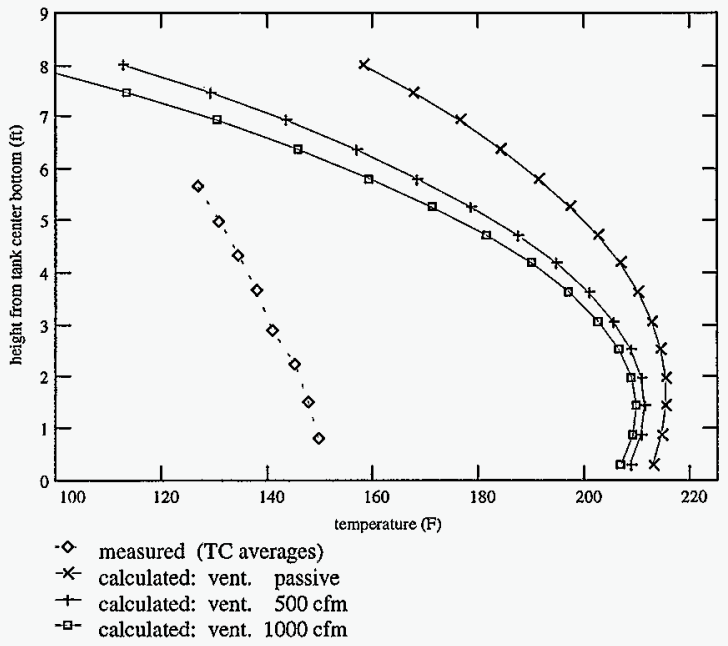


Figure 5.2.6. Tank 241-SX-110 Temperatures: Measured and Calculated. Temperatures: TC tree in riser \#12 (29 ft from center of tank)

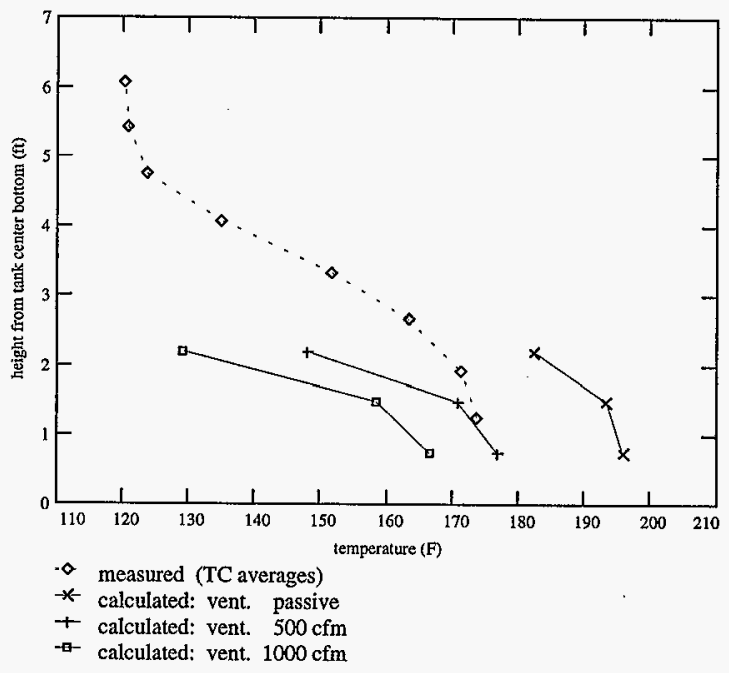

Temperatures: $\mathrm{TC}$ tree in riser $\# 20$ (19 ft from center of tank)

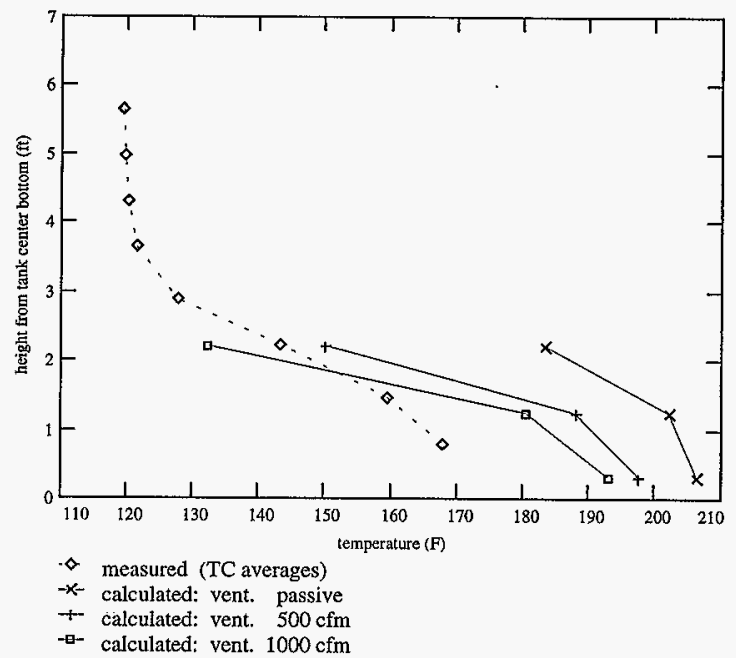


Figure 5.2.7. Tank 241-SX-111 Temperatures: Measured and Calculated. Temperatures: $\mathrm{TC}$ tree in riser \#10 ( $29 \mathrm{ft}$ from center of tank)

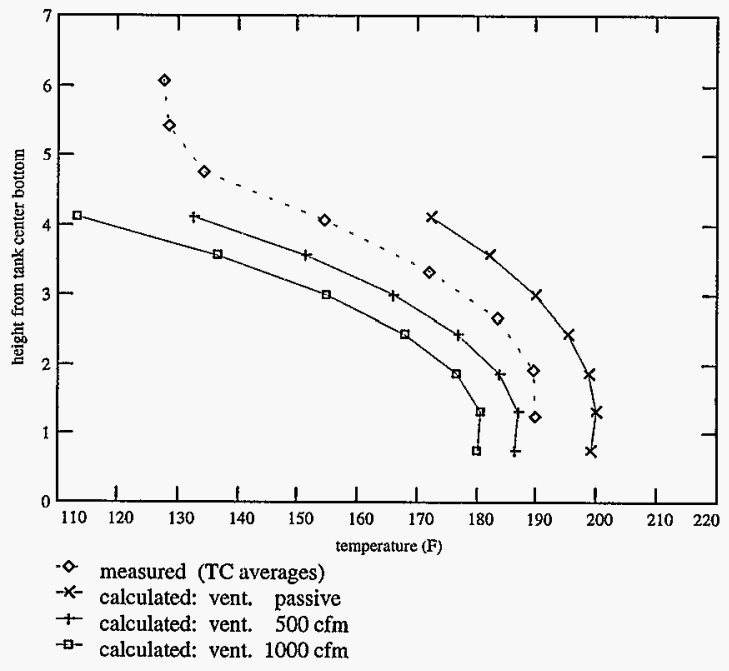

Temperatures: TC tree in riser $\# 19$ (19 ft from center of tank)

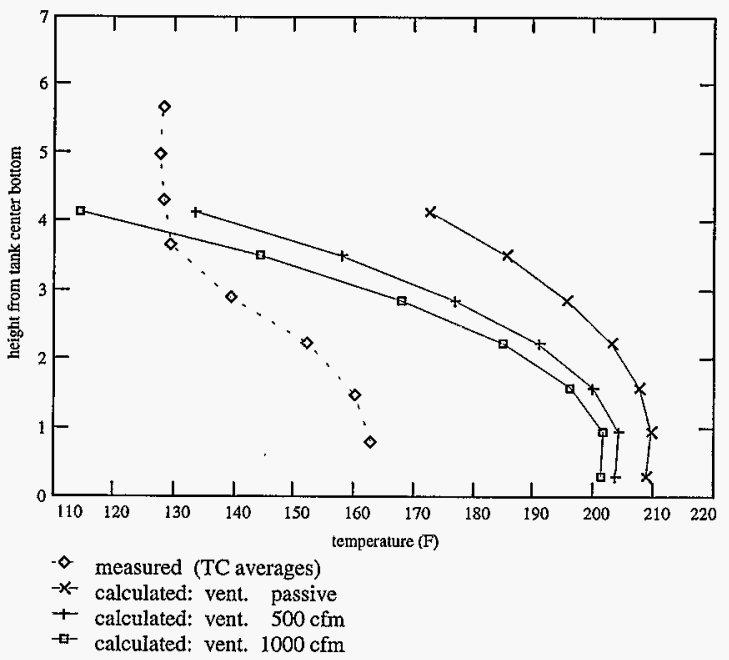


Figure 5.2.8. Tank 241-SX-112 Temperatures: Measured and Calculated. Temperatures: TC tree in riser \#10 (29 ft from center of tank)

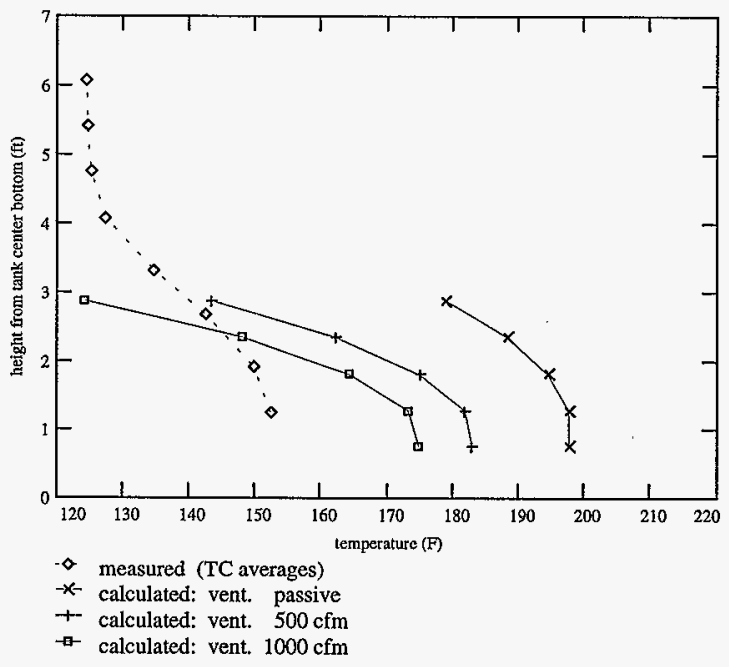

Temperatures: TC tree in riser \#19 (19 ft from center of tank)

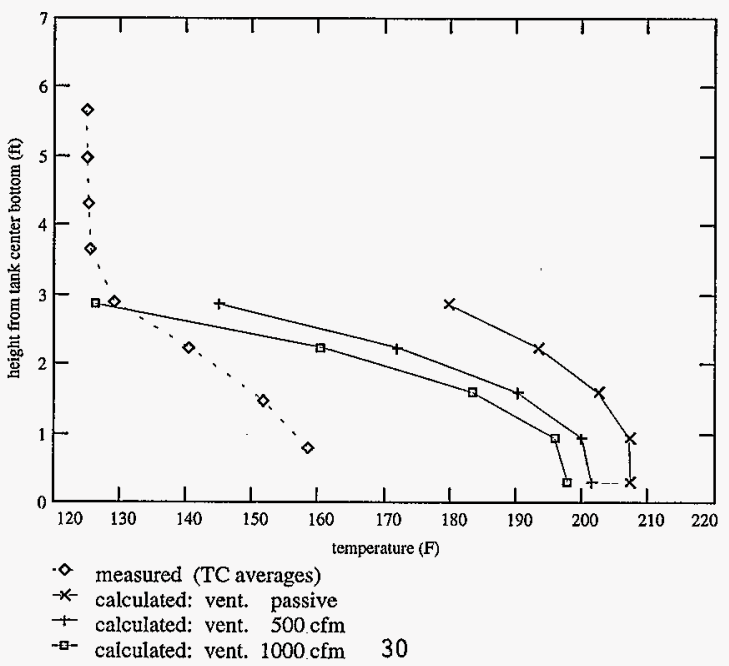


Figure 5.2.9. Tank 241-SX-114 Temperatures: Measured and Calculated. Temperatures: TC tree in riser \#10 ( $29 \mathrm{ft}$ from center of tank)

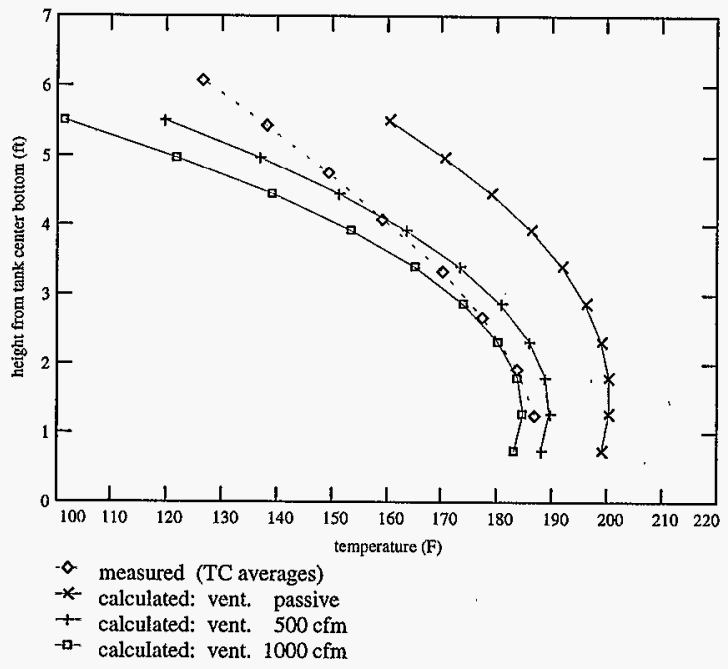

Temperatures: TC tree in riser \#19 (19 ft from center of tank)

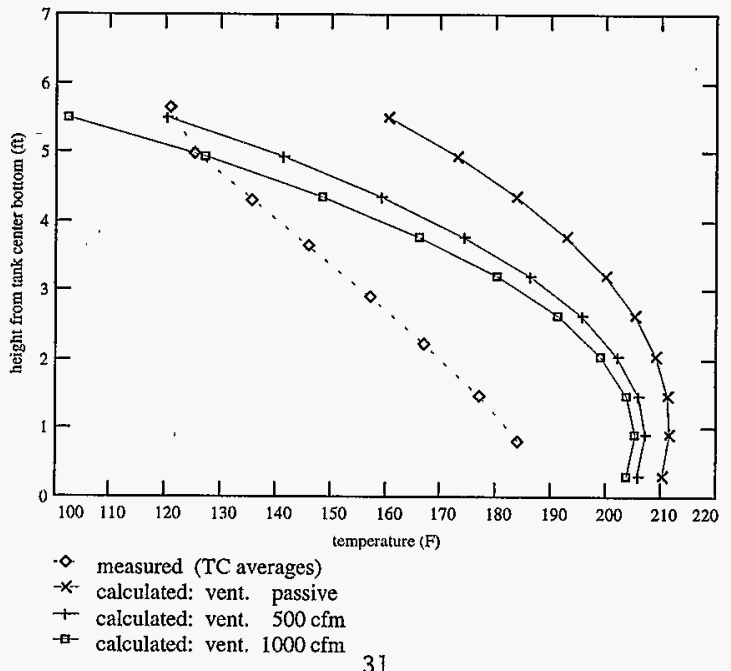




\subsection{RECOMMENDATIONS FOR FURTHER WORK}

S7udge samples should be obtained from tanks 241-SX-107, 241-SX-110, 241-SX-111, and 241-SX-114 to try to get a handle on the moisture present. This would provide the information to determine what type of further analyses are needed for these tanks.

\subsection{REFERENCES}

Alstad, A. T., 1993, Riser Configuration Document for Single-Shell Waste Tanks, WHC-SD-RE-TI-053, Rev. 9, Westinghouse Hanford Company, Richland, Washington.

Bander, T. J., 1992, Therma 7 History of Tank 241-C-106, WHC-SD-WM-ER-161, Rev. 0 , Westinghouse Hanford Company, Richland, Washington.

Dougherty, L. F., 1996, Single-She17 Tanks Interim Operational Requirements, WHC-SD-WM-OSR-005, Rev. 0-C, Westinghouse Hanford Company, RichTand, Washington.

Kreith, F., 1959, Principles of Heat Transfer, International Textbook Company, Scranton, Pennsylvania.

PATRAN, 1990, PATRAN Plus User Manuals, ReTease 2.5, PDA Engineering, PATRAN Division, Costa Mesa, California.

P/THERMAL, 1991, P/THERMAL Release 2.5 Notes, PDA Engineering, PATRAN Division, Costa Mesa, California.

P/VIEWFACTOR, 1991, P/VIEWFACTOR Release 2.5 Notes, PDA Engineering, PATRAN Division, Costa Mesa, California.

Stone, W. A., J. M. Thorp, O. P. Gifford, and D. J. Hoitink, 1983, C7imatological Summary for the Hanford Area, PNL-4622, Pacific Northwest Laboratories, Richland, Washington. 


\section{DISTRIBUTION SHEET}

\begin{tabular}{|c|c|c|c|c|c|}
\hline \multirow{2}{*}{$\begin{array}{l}\text { To } \\
\text { Distribution }\end{array}$} & \multirow{2}{*}{\multicolumn{3}{|c|}{$\begin{array}{l}\text { From } \\
\text { Process Engineering Analysis }\end{array}$}} & \multicolumn{2}{|l|}{ Page 1 of 1} \\
\hline & & & & \multicolumn{2}{|c|}{ Date $10 / 14 / 96$} \\
\hline \multicolumn{4}{|l|}{ Project Title/Work Order } & \multicolumn{2}{|c|}{ EDT No. 614688} \\
\hline \multicolumn{4}{|c|}{$\begin{array}{l}\text { Temperature Limits Based on the Saturation Temperature in } \\
\text { Hanford Waste Storage Tanks/N2218 }\end{array}$} & \multicolumn{2}{|c|}{ ECN No. $N / A$} \\
\hline Name & MSIN & $\begin{array}{l}\text { Text } \\
\text { With All } \\
\text { Attach. }\end{array}$ & Text Only & $\begin{array}{l}\text { Attach./ } \\
\text { Appendix } \\
\text { Only }\end{array}$ & $\begin{array}{l}\text { EDT/ECN } \\
\text { Only }\end{array}$ \\
\hline $\begin{array}{l}\text { D. A. Barnes } \\
\text { B. A. Crea } \\
\text { G. L. Dunford } \\
\text { D. M. Ogden } \\
\text { R. L. Schlosser } \\
\text { J. P. Sloughter } \\
\text { PEA Files (Burstad 2) } \\
\text { Central Files (Origina] + 2) }\end{array}$ & $\begin{array}{l}\text { R1-80 } \\
\text { S2-24 } \\
\text { A2-34 } \\
\text { HO-34 } \\
\text { R1-56 } \\
\text { R2-54 } \\
\text { HO-34 } \\
\text { A } 3-88\end{array}$ & $\begin{array}{l}X \\
X \\
X \\
X \\
X \\
X \\
X \\
X\end{array}$ & & & \\
\hline
\end{tabular}

